Original Research Report

\title{
Biochemical Profile and Antibacterial Examination of Freshwater Crab Scylla Serrata (FORSKAL, 1775)
}

\author{
Leena Grace Beslin ${ }^{1}$, Geni $\mathbf{G}^{2}$ \\ ${ }^{1}$ Department of Zoology, Nesamony Memorial Christian College. Marthandam, \\ Kanyakumari District, India. \\ ${ }^{1}$ Manonmaniam Sundaranar University, Abishekapatti. Tirunelveli - 627012, Tamil \\ Nadu, India.
}

Article History
Received:
09.07 .2021
Revised:
01.08 .2021
Accepted:
10.08 .2021
*Corresponding Author:
Leena Grace Beslin
Email:
drblgrace@rediffmail.com

This is an open access article, licensed under: $\mathrm{CC}-\mathrm{BY}-\mathrm{SA}$

\begin{abstract}
Natural products from the aquatic organisms provide unlimited opportunities for the production of new drugs. To verify this fact in the present study 'the biochemical profile and antimicrobial activity of different samples of the estuarine crab, Sylla serrata' was investigated. Biochemical study of the body parts of the crab gains substantial attention for their specificity in connection to the food values of the crab and for the evaluation of their physiological needs at different periods of life. The total protein was estimated by Lowry's method and the amount of protein was highest in the soft muscle sample $(20.27 \mathrm{mg} / \mathrm{ml})$. The total sugar was estimated by the Phenol-Sulphuric acid method and it was highest in the leg sample $(209.8 \mathrm{mg} / \mathrm{ml})$. The lipids of the samples were estimated by Folchs method. Lipid was highest in the shell sample $(28.35 \mathrm{mg} / \mathrm{ml})$. Thin Layer chromatography was done for characterization of protein. Antibiotics are used against bacterial infections. The natural products gained importance to screen antibiotics. For this reason the antibacterial activity of the samples were tested against grampositive and gramnegative pathogenic bacterial strains. The bacterial strains like Klebsiella pneumoniae, Staphylococcus aureus, Pseudomonas aeruginosa, Escherichia coli and Enterobacter aerogenes were used as the test strains. In the present study, the ethanol extract of crab sample I showed maximum zone of inhibition $(13 \mathrm{~mm})$ in P.aeruginosa. The sample I showed moderate zone of inhibition $(11 \mathrm{~mm})$ in K.pneumoniae. The sample II showed the minimum zone of inhibition $(7 \mathrm{~mm})$ in P.aeruginosa. It indicated that the shell of crabs would be a good source of antimicrobial agents and would replace the existing inadequate and cost effective antibiotics. The microbial associates of crustaceans have proven to be a rich source of bioactivity with antimicrobial and cytotoxic effects. So the organism used in the present study will be the promising source to the biotechnological and pharmaceutical applications.
\end{abstract}

Keywords: Antibiotics, Carbohydrate, Lipid, Protein, TLC. 


\section{Introduction}

Crab is an outstanding successful form of crustacean. The important edible varieties of crab belong to the family portunidae and are the most advanced members of the phylum Arthropoda. Crabs are excellent sources of high quality proteins which are superior to meat and poultry. The knowledge of the chemical composition of any edible organisms is extremely important since the nutritive value is reflected in its biochemical contents. Fewer species should be recommended for human consumption only after assessing the nutritive value of the species with regards to nutritional merits. Biochemical study of the body parts of the crab is of substantial attention for their specificity in connection to the food values of the crab and for the evaluation of their physiological needs at different periods of life. The biochemical energy is stored in response to the changing environmental circumstances, the ability of animal to convert environmental energy into biologically functional units and for the periods of increased biosynthetic activities such as reproduction and growth. In general energy is stored prior to gametogenesis when food is abundant in the form of glycogen, protein and lipid.

Crabs are highly nutritious and healthy owing to its protein content, unsaturated fatty acids, Carbohydrates and mineral composition. Therefore determining the proximate composition and mineral elements of crab species has a great importance due to the fine effect on human health. The prospective health benefits related to crab consumption are because of the presence of proteins, vitamins and essential unsaturated fatty acids. Crab is also a good source of various minerals. Proximate biochemical analysis provides information on the nutritional value of S.serrata to evaluate the medical value and as a source of food.

Rajkumar et al. [1] investigated the estimation of biochemical composition of Porpita porpita. The evaluation of the biochemical composition of P.porpita clearly indicated the higher biochemical composition comparable to those reported for several other plankton species. James chakraborthy et al. [2] studied the growth, survival and biochemical composition of freshwater prawns Macrobrachium rosenbergii fed with natural food organisms under controlled conditions. Giese [3] studied the biochemical composition of mollusc body. He showed that the molluscs restrain large amount of protein.

Costa et al. [4] studied the biochemical composition and physiological responses of two clam species. This study results proved that the clam species contains more amount of protein. Balasubramanian and Susselan [5] studied the biochemical composition of the deep water crab Charybdis smithii. The protein and carbohydrate content of C.smithii are more or less similar to that of other Portunid crabs. Rosa and Nunes [6] studied the biochemical composition of deep sea decapod crustaceans with two different benthic life strategies at the Portuguese South Coast. They accounted the biochemical changes were observed in single populations and would be influenced or synchronized with food availability and activity of crustaceans.

Sonia Baklouti et al.[8]reported the proximate composition and its seasonality of the Mediterranean green Crab: Carcinus aestuarii (Brachyura, Portunidae), in Southern Tunisian waters (Central Mediterranean region). This study was performed to know the biochemical compositions which were influenced by sex, age and seasons. Bokulmia et al. [9] investigated the morphology and biochemical composition of crab Paratelphusa lamellifrons in Bangladesh. They investigated the freshwater crabs were regarded as a good source of protein and recommended as an ideal food item. Jelin and Keerthika [10] reported the biochemical composition of marine crab Ocypode brevicornis and estuarine crab Scylla serrata. This research indicated the crabs could be employed as a supplement of protein and as a balanced human nutrition.

Anything that destroys bacteria or suppresses their growth or their ability to reproduce is known as antibacterial activity. Crabs are potential sources of new antibiotics. The search for antimicrobial agents has taken a definite direction in developed countries. The first line defense of arthropods is their physical nature of their hard cuticle against pathogens and parasites. Once this barrier is passed, a complex interaction of innate humoral and cellular immune reactions are induced in both tissues and haemocoel which results in a fast elimination of microorganisms. Antimicrobial activity refers to the process of killing or inhibiting the disease causing microbes. Various antimicrobial agents such as plants and plant products, organisms and their products and herbal plants were used for the antimicrobial activity. Antimicrobial may be antibacterial, antiviral and antifungal. They all have different modes of action by which they act to suppress the infection.

Nowadays antibiotics are used against the bacterial infections. But these antibiotics have become less and less effective against particular pathogen. The harmful microorganisms can be controlled 
with drugs which lead to the appearance of multiple drug resistant bacteria. It has created warning clinical situations in the treatment of infections. The pharmacological industries have produced a number of new antibiotics which rooted resistance to these drugs due to amplified microorganisms. In general bacteria have the genetic ability to transmit and acquire resistance to synthetic drugs which are utilized as therapeutic agents. Immense attention has been focused concerning the development of new antimicrobial agents for the treatment of bacterial infections. Although pharmaceutical industries have produced a number of new antimicrobial drugs in the last few years, resistance to these drugs by microorganisms has also risen rapidly. Approximately 16,000 marine natural products were employed in antibacterial agents for the treatment of bacterial infection.

Ewa Felis et al. [11] investigated the antimicrobial pharmaceuticals in the aquatic organisms and their results showed that the occurrence and abundance of antimicrobial pharmaceuticals in the aquatic environment in context to the adverse effects caused directly by these substances and the threat associated with the antibiotics resistance phenomenon.

Veeruraj et al. [12] examined the antibacterial activity of crab haemolymph on clinical pathogens. Their study indicated the haemolymph of crabs would be a good source of antimicrobial agents. Varadharajan and Soundarapandian [13] investigated the antibacterial activity of crab shell extracts against human pathogenic bacteria and usage of drugs. In this investigation the chitin extracted from Scylla serrata exhibited vital antibacterial activity against the pathogenic bacterial strain Staphylococcus aureus. Du-Tie ping et al. [14] studied the antibacterial activity of extracts from ink sac of cuttle fish on bacteria Staphylococcus aureus and E. coli.

Matteo Dell Anno et al. [15] studied the invitro evaluation of antimicrobial and antioxidant activities of algal extracts. This evaluation showed the invivo bioactive products. Anitha Muthusamy et al. [7] studied the Phytochemical screening of Datura Metel Linn and its antimicrobial activity on human pathogens. This study explained the isolation and identification of active principles present in the extracts which could be used for pharmaceutical purpose. The aim of our present study is to analyze the biochemical profile prior to bioactive compounds identification. The present study represents an attempt to investigate the biochemical profile and natural antibacterial activities from whole extract of Scylla serrata. So the current study focuses to evaluate the antimicrobial activity of five different groups of bacterial agents by comparing it with selected antibiotics for the treatment and manifestations caused by microorganisms.

\section{Material and Methods}

\subsection{Collection of Sample}

The field crab Scylla serrata was collected from the natural habitat of the creeks of the river Thamirabarani and nearby paddy fields located at Kuzhithurai, Kanyakumari District for the experimental purpose. The entire portion of the crabs were separated into three parts and made into 3 different samples. In the present study these samples were used to find out biochemical contents and their antibacterials.

\subsection{Description of Experimental Organism}

Scylla serrata is habitually called mud crab or mangrove crab. It is an ecologically important species of crab found in the estuaries, rivers and paddy fields. The shell colour varies from a deep mottled green to very dark brown. The natural origin of Scylla serrata is in the Indo-Pacific. It is also found in South Africa and around the coast of India. These crabs are highly cannibalistic in nature; when crabs undergo molting other hard shelled ones sometimes attack the molting crabs and devour them. The females reproduce a million offspring which can grow up to $3.5 \mathrm{~kg}$ in size and have a shell width of up to $24 \mathrm{~cm}$ wide. It can be kept easily in home aquaria when smaller but will escape from small setups. They are tolerant of most water conditions and are generally a very hardy and entertaining species.

\subsection{Preparation of Animal Extract}

The samples were collected and washed with distilled water. Then the complete animal body was categorized into three portions as sample I, sample II and sample III. With the help of fine sterile scissors and forceps shells, muscles and legs were separated. All the three samples were separately dried in shade. After that they were grained well and stored at 4 degree Celsius for further analysis. 


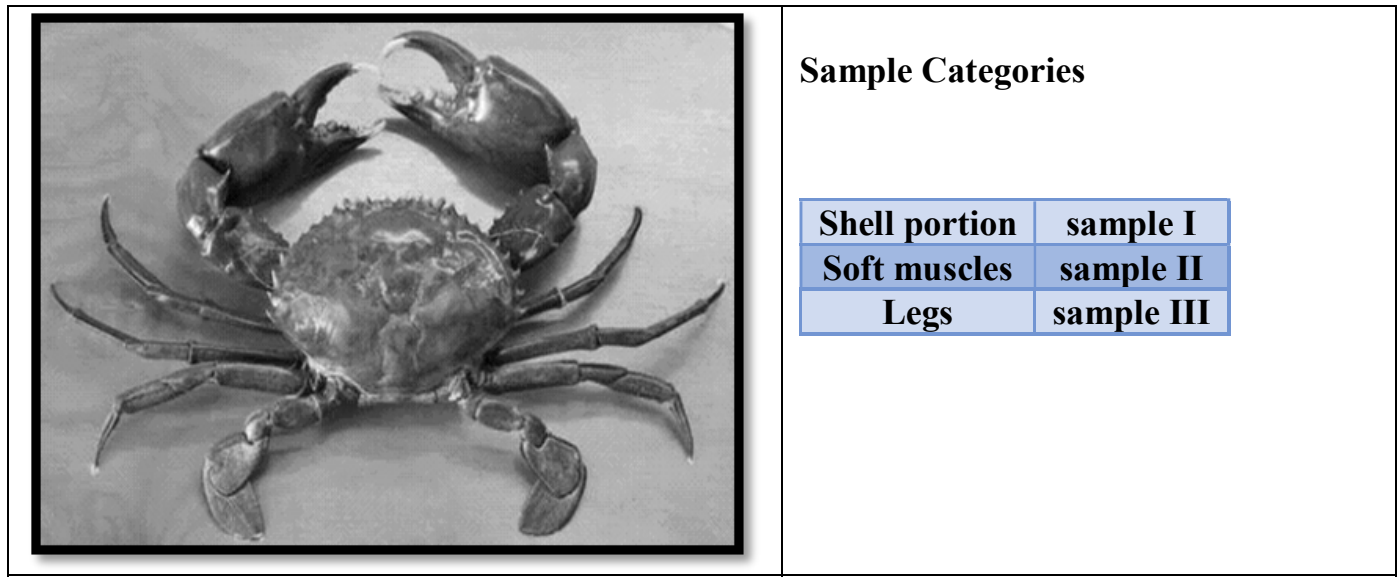

Figure 1. Entire View of Scylla Serrata

\section{Biochemical Analysis}

The present study was associated to know the biochemical composition of the crab Scylla serrata. In the three different samples proteins, carbohydrates and lipids were analysed and evaluated [16].

\section{Estimation of Proteins}

The total protein content was estimated in three different samples of crab using Lowry's method. The principle behind the Lowry method of determining protein concentrations lies in the reactivity of the peptide nitrogens with the copper ions under alkaline conditions and the subsequent reduction of the Folin-Ciocalteau phosphomolybdic phosphotungstic acid to heteropoly molybdenum blue by the copper catalyzed oxidation of aromatic acids. The Lowry method is sensitive to $\mathrm{pH}$ changes and therefore the $\mathrm{pH}$ of assay solution should be maintained at 10-10.5. The Lowry method is sensitive to low concentrations of protein. A variety of compounds will interfere with the Lowry procedure. These include some amino acid derivatives, certain buffers, drugs, lipids, sugars, salts, nucleic acids and sulphydryl reagents. These substances should be removed or diluted before running Lowry assays [17].

With $0.1 \mathrm{gm}$ of powdered weighed samples, $1 \mathrm{ml}$ of double distilled water was added. Samples were homogenized in $1 \mathrm{~N} \mathrm{NaOH}$ and centrifuged at $5000 \mathrm{rpm}$ for 10 minutes. The supernatant was discarded. The precipitate was dissolved in $1 \mathrm{ml}$ of $0.1 \mathrm{~N} \mathrm{NaOH}$. An aliquot of $1 \mathrm{ml}$ sample was mixed with $50 \mathrm{ml}$ of alkaline copper sulphate reagent was added and mixed well by vigorous shaking and allowed to stand at room temperature for about 10 minutes. After that $0.6 \mathrm{ml}$ of Folin-Ciocalteu reagent (1:1 Folin-Ciocalteu : distilled water) was added and mixed thoroughly and incubated at room temperature for about 20 minutes and OD was taken at $625 \mathrm{~nm}$.

The values were calculated against Bovine Serum Albumin (BSA) which was used as standard.

$$
\text { Total protein }=\frac{\text { Sample OD }}{\text { Standard OD }} \times 0.1
$$

\section{Estimation of Carbohydrates}

The total carbohydrate was estimated in the three crab samples by using Phenol Sulphuric acid method [18]. Concentrated Sulphuric acid causes hydrolysis of glycosidic linkages; these hydrolysed neutral sugars are then partially dehydrated with the elimination of three molecules of water to form furfural derivatives. The coloured compounds developed by the condensation of furfural derivatives with phenol are measured at $490 \mathrm{~nm}$. 
To $1 \mathrm{ml}$ of sample, $1 \mathrm{ml} 5 \%(\mathrm{w} / \mathrm{v})$ phenol was added followed by $5 \mathrm{ml}$ concentrated Sulphuric acid. The sample tubes were kept in ice while adding sulphuric acid. The mixture was incubated at room temperature for 20 minutes and the absorbance was read at $490 \mathrm{~nm}$.

$$
\text { Total carbohydrate }=\frac{\text { OD of standard }- \text { OD of sample }}{\text { Weight of the sample }} \times 100
$$

Glucose was used as the standard in the range of $0-100 \mu \mathrm{g}$ concentration from $1 \mathrm{mg} / 1 \mathrm{ml}$ stock solution. A blank was also prepared in the same way ( $0 \mathrm{mg}$ glucose).

\section{Estimation of Lipids}

The lipids of crab samples were estimated by the method of Folch et al. [19]. Folch's extraction procedure is one of the most popular methods for isolating lipids from biological samples. It takes advantage of the biphasic solvent system consisting of chloroform, methanol and water in a volumetric ratio of $8: 4: 3(\mathrm{v} / \mathrm{v} / \mathrm{v})$. The samples were extracted with chloroform: methanol $(2: 1 \mathrm{v} / \mathrm{v})$.

The shell, legs and muscle tissue was cut from the fresh crab, rinsed with distilled water and dried to constant weight in a drying oven (60 degree celcius, $24 \mathrm{~h})$. Dried samples were minced in a glass blender homogenized with chloroform: methanol mixture $(2: 1 \mathrm{v} / \mathrm{v})$, mixed and vortex at $2800 \mathrm{rpm}$ and equilibrated with about $20 \%$ of its volume of a saline solution. The extracted lipids were weighed and calculated.

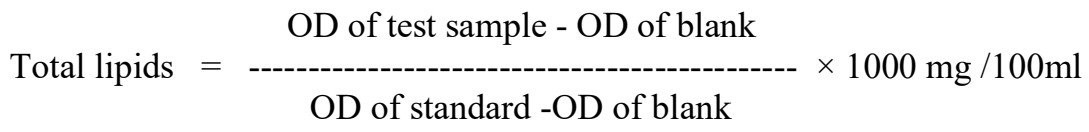

\section{Thin Layer Chromatography}

Thin Layer Chromatography (TLC) is a technique used to isolate non volatile mixtures by which the compounds present in the mixture were separated [19]. It is a solid-liquid technique in which the two phases are a solid (Stationary phase) and a liquid (Moving phase).

Development consist of placing the bottom of the TLC plate into a shallow pool of a development solvent which then travelled up the plate by capillary action. The experiment is conducted on a sheet of aluminium foil, plastic or glass which is coated with a thin layer of absorbent material. The material usually used is silica gel. $5 \mathrm{ml}$ of the crude extract was spotted on a preparative TLC (Thin Layer Chromatography) plate coated with silica gel (thickness $0.5 \mathrm{~mm}$ ) dried and kept in the saturated twin trough chamber containing butanol:methanol:water in the ratio of 3:1:1 as a mobile phase and developed up to $9 \mathrm{~cm}$ length. The development of the sample spots were done using twin trough chamber. Once the spots were developed, the plates were taken out and dried them. The sample spots can be observed under a UV light chamber. On completion of the separation, each component appears as separated spots vertically. Each spot has a Retention factor (Rf) expressed as:

$$
\begin{aligned}
& \text { Distance travelled by sample } \\
& \text { Rf = ------------------- }
\end{aligned}
$$

\subsection{Antimicrobial Activity of Crab Samples}

Antimicrobial activity refers to the destructive or inhibitive growth of microorganisms. A variety of laboratory methods can be used to evaluate or screen the invitro antimicrobial activity of an extract or a pure compound. The most known and basic methods are the disk diffusion and broth or agar dilution methods. For the present study antimicrobial activity of three different portions considered as distinct samples from the crab Scylla serrata [20]. 


\section{Preparation of Crude Extract}

$1 \mathrm{gm}$ of dried powdered samples were macerated with $80 \%$ ethanol for one hour and then filtered. The filtrate was evaporated to a thick residue at 40 degree Celsius.

\section{Preparation of Extract Solution}

One gram of each sample was dissolved in $10 \mathrm{ml}$ of ethanol. Then the samples were kept in a water bath for 20 minutes at 100 degree Celsius to dissolve the samples into the solvent.

\section{Test Microorganisms}

Five types of pathogenic bacteria such as Klebsiella pneumoniae, Staphylococcus aureus, Pseudomonas aeruginosa, Escherichia coli and Enterobacter aerogenes were used for antibacterial studies.

1. Klebsiella pneumoniae

K.pneumoniae is gramnegative, non-motile, encapsulated, lactose fermenting, facultative anaerobic, rod shaped bacterium. It appears as a mucoid lactose fermenter on Mac conkey agar. It is found in the mouth, skin and intestines. It is an important pathogen in nosocomial infections. It naturally occurs in the soil and about $30 \%$ of strains can fix nitrogen in anaerobic conditions.

2. Staphylococcus aureus

S.aureus is a grampositive, non-motile and non-spore forming bacterium. It occurs in clusters. It is a facultative anaerobic bacterium. S.aureus may occur on the human skin, nose and throat. They are frequently surrounded by zones of clear beta haemolysis.

3. Pseudomonas aeruginosa

P.aeruginosa is a gramnegative, rod-shaped and mono flagellated bacterium. It is a rod about $1-5 \mu \mathrm{m}$ long and $0.5-1.0 \mu \mathrm{m}$ wide. It is an obligate respirator. This bacterium is found in environments such as soil, water, humans, animals, plants, sewage and hospitals. P.aeruginosa is an opportunistic human pathogen.

4. Escherichia coli

E.coli is a gramnegative, facultative anaerobic, rod shaped coliform bacterium. It is commonly found in the lower intestine of warm blooded organisms (endotherms). E.coli is expelled into the environment with faecal matter. It served as the host organism for recombinant DNA. It is the most studied prokaryotic model organism in the field of biotechnology and microbiology.

5. Enterobacter aerogenes

E.aerogenes is a gramnegative bacterium. It is rod shaped having variety of sizes. It is non spore forming and is both motile and non motile. It grows both aerobically and anaerobically. This bacterium consists of circular DNA. It contains no structural RNAs.

\section{Subculturing of Bacterial Strains}

The bacterial strains were subcultured in nutrient agar medium (g/l) (peptic digest of animal tissue $5 \mathrm{~g}$, sodium chloride $-5 \mathrm{~g}$, beef extract $-1.5 \mathrm{~g}$, yeast extract $-1.5 \mathrm{~g}$ and agar $-15 \mathrm{~g}$ ). Later all cultures were maintained at 4 degree Celsius for further studies.

\section{Antibiotics}

Antibiotics were used as positive control during antimicrobial activity studies. These were purchased from Himedia, Mumbai, India. Amikacin $(10 \mu \mathrm{g})$ was used as the positive control.

\section{Inoculum Preparation}

The selected bacterial isolates were cultured individually in the basal medium. The composition of basal medium consists of $(\mathrm{g} / \mathrm{l})$ was glucose $-0.5 \mathrm{~g}$, yeast extract $-0.1 \mathrm{~g}$, peptone $-0.25 \mathrm{~g}$, KH2Po4 $0.05 \mathrm{~g}, \mathrm{MgSo} 4-0.01 \mathrm{~g}$ and $\mathrm{Nacl}-1.0 \mathrm{~g}$. The medium $\mathrm{pH}$ was adjusted to 7.0 by using $\mathrm{HCl} / \mathrm{NaOH}$. Then the isolates were inoculated individually and incubated at 37 degree Celsius for 24 hours. The bacterial growth was measured by monitoring the absorbance at $600 \mathrm{~nm}$ in a UV-visible spectrophotometer. After incubation, it was stored at 2- 8 degree Celsius for further studies. 


\section{Antibacterial Screening}

The ethanol solvent fractions were evaluated for antibacterial activity against five bacterial strains such as Klebsiella pneumoniae, Staphylococcus aureus, Pseudomonas aeruginosa, Escherichia coli and Enterobacter aerogenes. Muller Hinton Agar (g/l) (Beef infusion form - 300, casein acid hydrolysate -17.5, Starch -1.5 and agar -17) (Himedia, Mumbai, India) was prepared in Erlenmeyer flask according to the manufactures instructions.

The media along with pipette, Petri dishes and metallic borer were sterilized in an autoclave at 121 degree Celsius for 15 minutes. The culture media was finally poured into Petri dishes under sterile condition [23]. All the solvent extracts were dissolved in dimethyl sulfoxide (DMSO) (100\%) to achieve a final concentration of $20 \mathrm{mg} / \mathrm{ml}$.

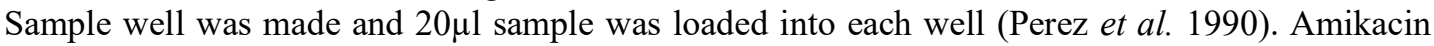
$(10 \mu \mathrm{g})$ was used as the positive control and DMSO was used as the negative control. All plates were incubated for $24 \mathrm{~h}$ at 37 degree Celsius. The diameter of the zone of inhibition was measured in millimetre $(\mathrm{mm})$.

\section{Result}

\subsection{Biochemical Composition of S.Serrata}

The results obtained in the present study revealed significant variations in the concentration of Protein, Carbohydrate and Lipid in various body parts of S. serrata. The biochemical constituents of the body parts of S.serrata were shown in the Figure 2, Figure 3 and Figure 4 of all the biomolecules analyzed, high level of carbohydrate were observed.

Sample III of S.serrata contains low amount of protein $(7.9 \mathrm{mg} / \mathrm{ml})$, Sample I contains $8.71 \mathrm{mg} / \mathrm{ml}$ of protein content whereas the sample II contains high amount of Protein content $(20.27 \mathrm{mg} / \mathrm{ml})$.

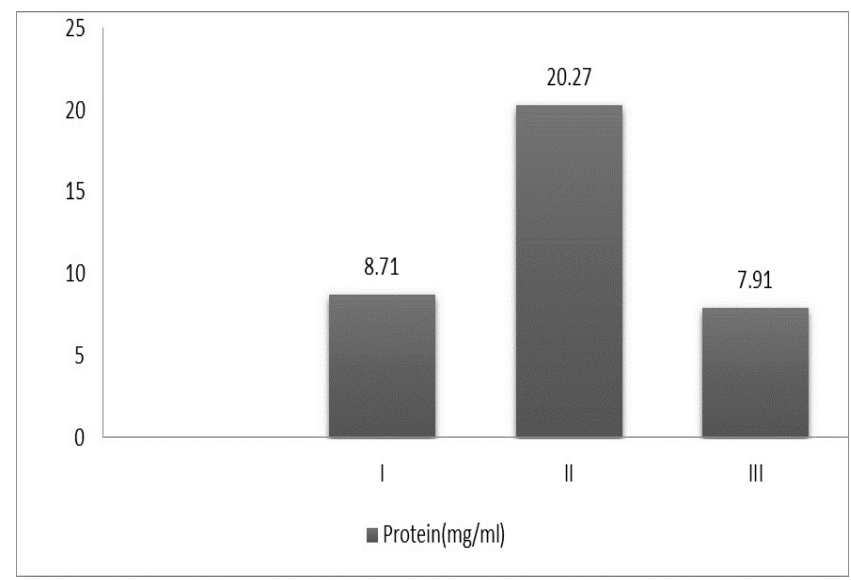

Figure 2. Composition of Protein in S. serrata

In S. serrata, carbohydrate content was measured in all the three samples. The carbohydrate content was different in all the three body parts. Carbohydrate content was higher in legs $(209.8 \mathrm{mg} / \mathrm{ml})$. The muscles of S.serrata contain low amount of carbohydrate $(130 \mathrm{mg} / \mathrm{ml})$. The shells contain moderate amount of carbohydrate $(171.7 \mathrm{mg} / \mathrm{ml})$. As shown in Figure 3.

The lipid content was higher in the shell sample $(28.35 \mathrm{mg} / \mathrm{ml})$. The leg sample contain lower amount of lipid content $(5.1 \mathrm{mg} / \mathrm{ml})$. The muscle sample having the minimum amount of lipid content $(5.89 \mathrm{mg} / \mathrm{ml})$. As shown in Figure 4.

The $R f$ values of samples were shown in figure 4 and the chromatogram is shown in picture 3 . The retention factors were higher in the sample III (0.76) and lower in the sample II $(0.70)$. The muscle sample having the minimum $R f$ value of 0.74 . As shown in Figure 5. 
Leena Grace Beslin, Geni G.

Biochemical Profile and Antibacterial Examination of Freshwater Crab Scylla Serrata (FORSKAL, 1775).

International Journal of Clinical Inventions and Medical Sciences, vol. 3, no. 2, pp. 53-65, September 2021. DOI: 10.36079/lamintang.ijcims-0302.233

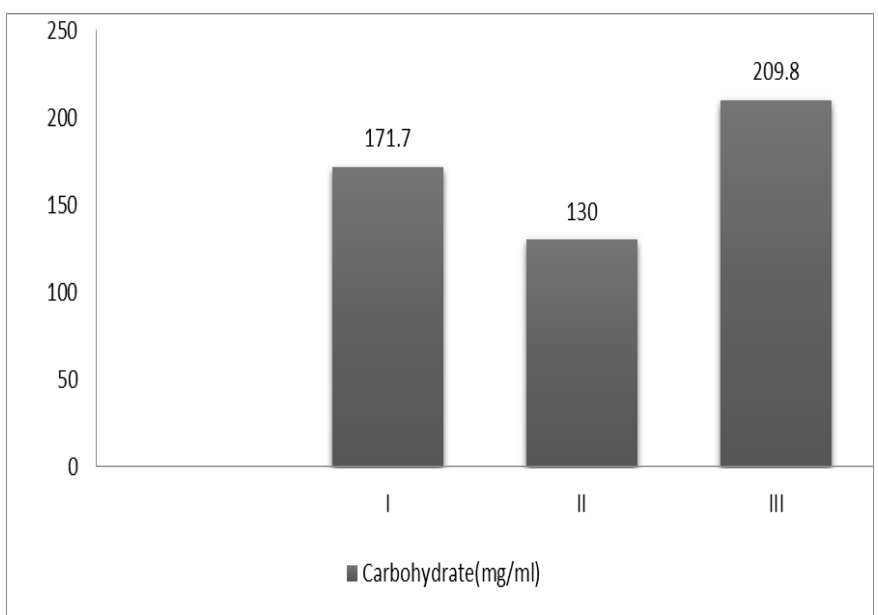

Figure 3. Composition of Carbohydrate in S. serrata

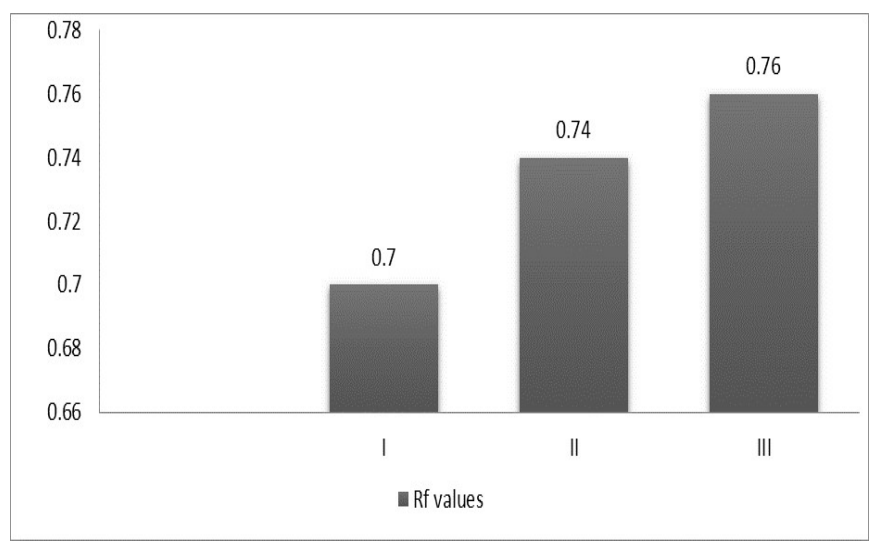

Figure 4. Composition of Lipida in S. serrata

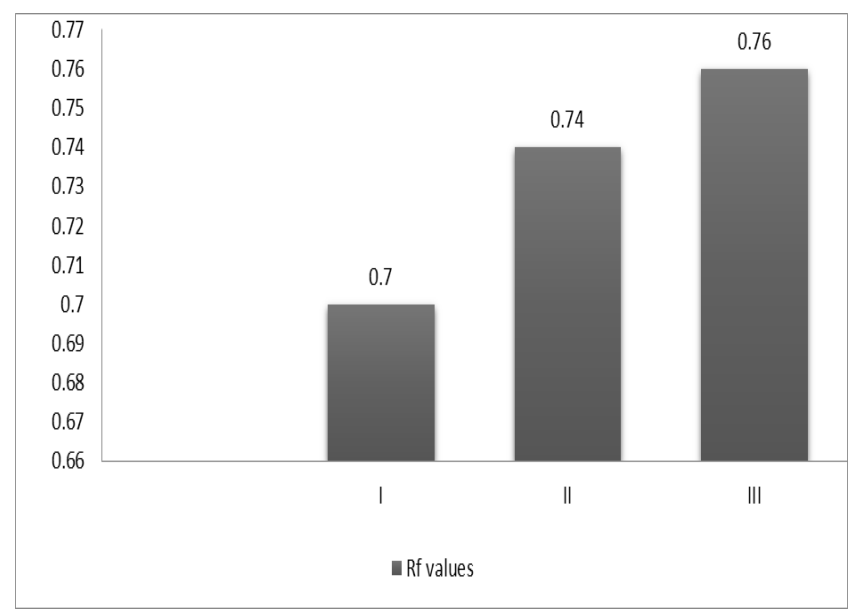

Figure 5. Rf Values of TLC in S. serrata 


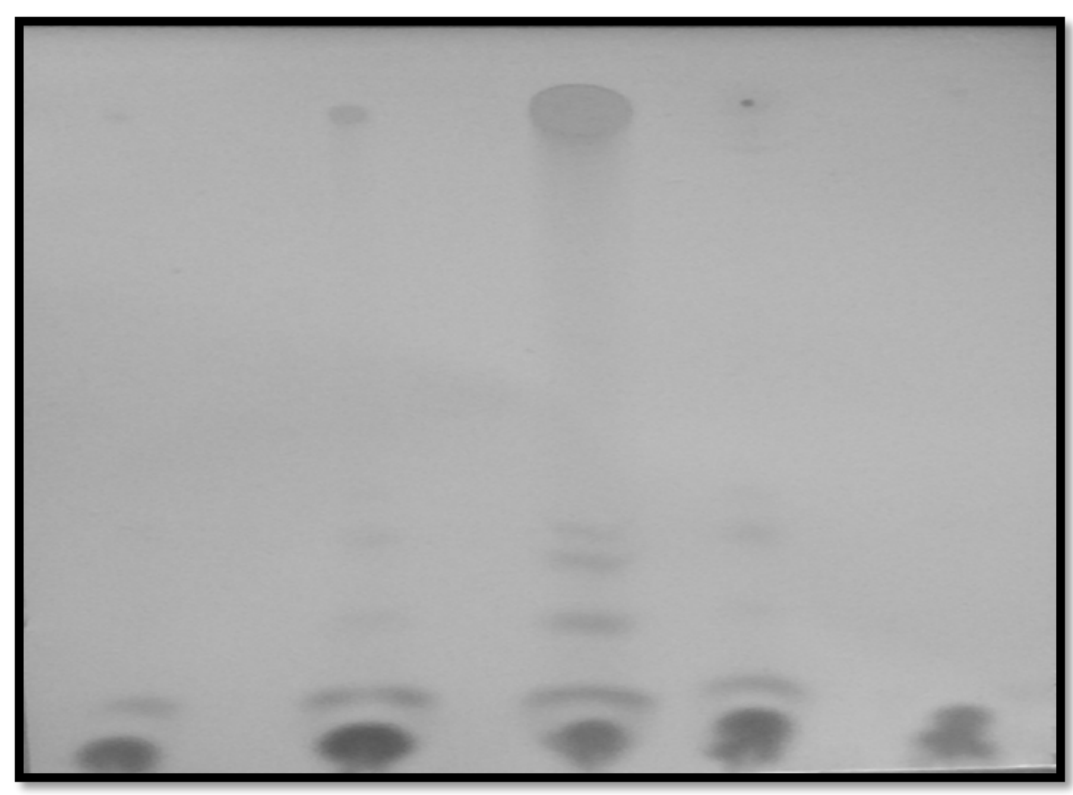

Figure 6. Thin Layer Chromatogram Run with S.serrata Sample

\subsection{Antimicrobial Activity of $S$. serrata}

The present study carried out on the crab samples to evaluate antimicrobial activities of various parts of the Scylla serrata. Table 1 shows the zones of inhibition in the ethanolic extracts of the crab samples. The successive ethanolic extracts of crab samples were tested for their antimicrobial efficiency against pathogenic bacteria such as Klebsiella pneumoniae, Staphylococcus aureus, Pseudomonas aeruginosa, Escherichia coli and Enterobacter aerogenes (Figure 7).

Table 1. Zones of Inhibition in S.serrata Samples

\begin{tabular}{lccc}
\hline BACTERIA & SAMPLE I & SAMPLE II & SAMPLE III \\
\hline K.Pneumoniae & $11 \mathrm{~mm}$ & $9 \mathrm{~mm}$ & $10 \mathrm{~mm}$ \\
\hline S.aureus & $9 \mathrm{~mm}$ & $8 \mathrm{~mm}$ & $8 \mathrm{~mm}$ \\
\hline P.aeruginosa & $13 \mathrm{~mm}$ & $7 \mathrm{~mm}$ & $10 \mathrm{~mm}$ \\
\hline E.coli & $8 \mathrm{~mm}$ & $8 \mathrm{~mm}$ & $9 \mathrm{~mm}$ \\
\hline E.aerogenes & $9 \mathrm{~mm}$ & $8 \mathrm{~mm}$ & $10 \mathrm{~mm}$ \\
\hline
\end{tabular}

In Escherichia coli, the sample III showed the highest inhibition zone ( $9 \mathrm{~mm})$. Sample I and sample II showed the minimum inhibition zone ( $8 \mathrm{~mm})$.

In Pseudomonas aeruginosa, the sample I showed the highest inhibition zone (13mm), Sample III showed the minimum inhibition zone $(10 \mathrm{~mm})$ and the sample II showed the lowest inhibition zone $(7 \mathrm{~mm})$.

In Enterobacter aerogenes, the sample III showed highest $10 \mathrm{~mm}$ inhibition zone, Sample I showed the minimum inhibition zone $(9 \mathrm{~mm})$ and Sample II showed the lowest inhibition zone $(8 \mathrm{~mm})$.

In Klebsiella pneumoniae, the sample I showed the highest inhibition zone (11mm), Sample III showed the minimum inhibition zone $(10 \mathrm{~mm})$ and the sample II showed the lowest inhibition zone (9mm).

In Staphylococcus aureus, the sample I showed the highest inhibition zone $(9 \mathrm{~mm})$. Sample II and sample III showed the minimum inhibition zone $(8 \mathrm{~mm})$. 


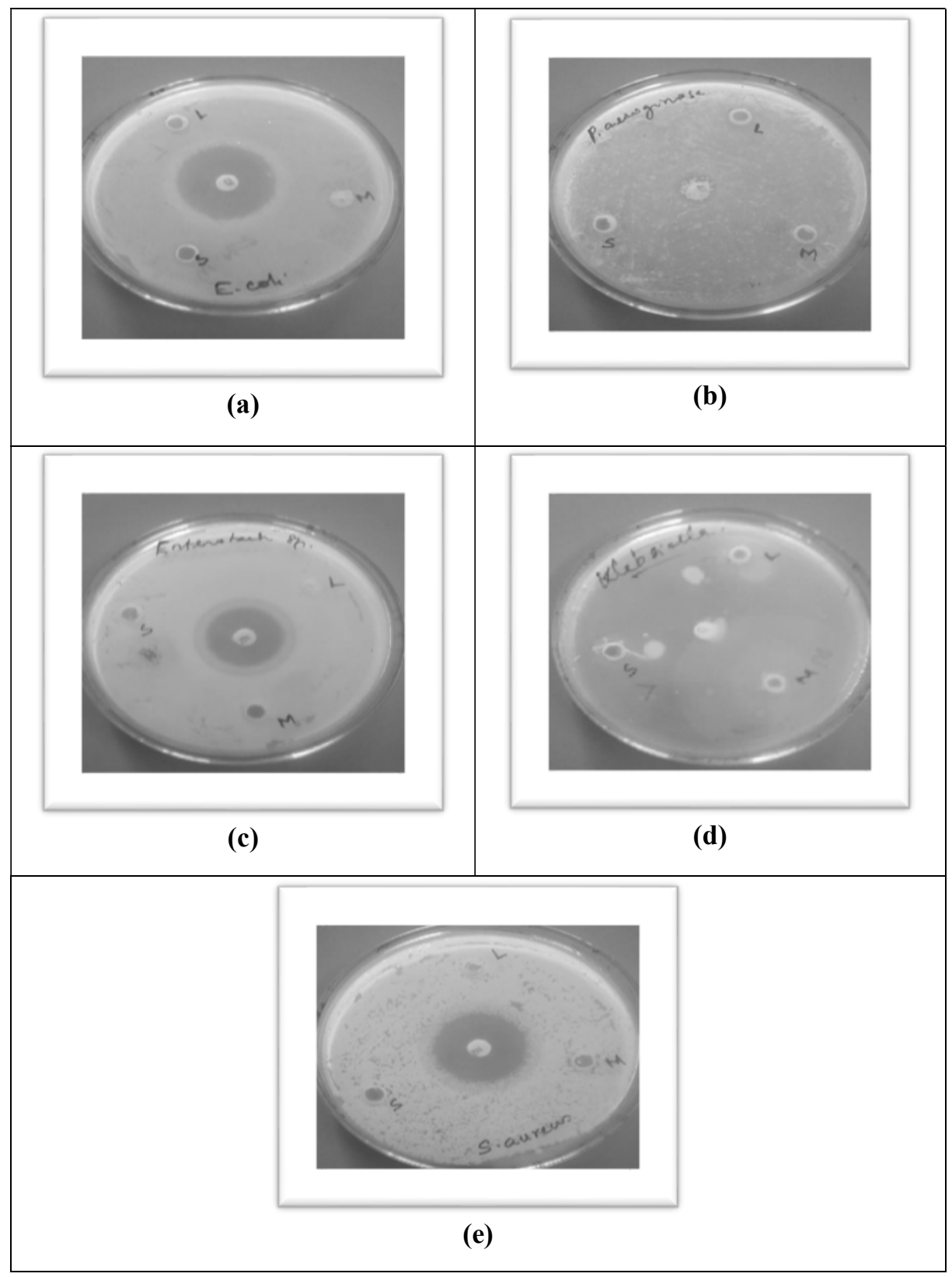

Figure 7. Agar Plate Showing Zones of Inhibition in S. serrata Extract Against:

(a) Escherichia coli

(b) Pseudomonas aeruginosa

(c) Enterobacter aerogenes

(d) Klebsiella pneumoniae

(e) Staphylococcus aureus

\section{Discussion}

Biochemical studies are vital from the nutritional point of view. The biochemical constituents in animals have known to vary with season, size of the animal, stage of maturity, temperature and availability of food [Fig 1-4]. An increasing demand for good quality animal protein for the exploding population has lead to effective and increasing exploitation of the aquatic resources. The biochemical components like carbohydrates, proteins and lipids are very much essential for growth 
and sustenance of life. Of these components, protein is the most prominent biochemical component of crustaceans from eggs to adults and is strikingly dominant in younger phases. In hard shelled crabs, highest amount of protein content was reported. The knowledge of biochemical composition of any edible organisms was extremely important because the nutritive value is reflected in its biochemical contents [21]. Protein is an important macronutrient and plays a vital role in determining the texture and quality of animal muscles.

In the present study, the protein content in sample II (muscle) is high $(20.27 \mathrm{mg} / \mathrm{ml})$.Similar study in the marine crab Ocypode brevicornis had $17.30 \mathrm{mg} / \mathrm{ml}$ in the thoracic muscle [10]. Balasubramanian and Susselan [5] elucidated that the deep water crab Charybdis smithi contain $22.35 \mathrm{mg} / \mathrm{ml}$ in the muscle sample. Compared with these studies, the estuarine crab S.serrata was having lesser amount of crude protein. These differences are related with omnivores feeding habit and adequate food present in the surrounding.

Carbohydrate is an essential compound of living cells as it supplies energy for physiological and metabolic process. It is considered as inexpensive fundamental source of nourishment and provided stability in diet. They are the chief energy source in human diet.

In the current study also the carbohydrate was high when compared with protein and lipids. The carbohydrate content in sample III (legs) was high $(209.8 \mathrm{mg} / \mathrm{ml})$. The carbohydrate content in the deep water crab Charybdis smithi in the leg muscle validated was $34.14 \mathrm{mg} / \mathrm{ml}$ [21]. The carbohydrate content was high in deep sea decapod crustaceans $(64.2 \mathrm{mg} / \mathrm{ml})$ in the leg muscle sample [22]. Mediterranean green crab, Carcinus aestuari confirmed that contain $74.08 \mathrm{mg} / \mathrm{ml}$ of carbohydrate. Similar study showed that the marine crab Ocypode brevicornis contain $(60 \mathrm{mg} / \mathrm{ml})$ in the leg sample [8]. When compared with these studies, the high carbohydrate content of S.serrata also agreed with the mentioned results [22].

Aquatic animal fats are good sources of essential fatty acids. These fatty acids play a vital role in human nutrition. In the present study, the lipid content in sample I was high $(28.35 \mathrm{mg} / \mathrm{ml})$. Similar study showed that the deep water crab Charybdis smithi inferred with $8.2 \mathrm{mg} / \mathrm{ml}$ lipid content in the carapace [25]. Bokul Mia et al. [9] elucidated that the crab Paratelphusa lamellifrons had $9.34 \mathrm{mg} / \mathrm{ml}$ lipid in the cephalothorax. Xing-Hong $\mathrm{Xu}$ et al. [26] elucidated that the female marine crab Charybdis japonica had $7.74 \mathrm{mg} / \mathrm{ml}$ lipid in the carapace. When compared with other studies, the lipid content of S.serrata is higher than the other variety of crabs. The results obtained in the present study have demonstrated that the $S$. serrata inhabiting estuary water were highly nutritious in terms of protein, carbohydrate and lipids.

Thin Layer Chromatography (TLC) is a technique used to isolate non-atile mixtures by which the compounds present in the mixture were separated. This was the most recent technique of absorption chromatography. TLC was a simple, quick, accurate and inexpensive procedure than paper chromatography. It was also used to support the identity of a compound in a mixture. When the $R f$ of a unknown compound is compared with the $\mathrm{Rf}$ of a known substance, we were able to predict the unknown compound. In the current study, the TLC was used to analyze the protein characterization. The butanol-methanol-water mixture of the crab samples yielded the $R f$ values of $0.70,0.74$ and 0.76 . Ethanol-methanol-water mixtures of the plant extracts yielded the compounds of secondary metabolites like flavanoids and cardiac glycosides [7]. When compared with these studies, the present study concluded that the certain amino acids were separated from the extracts of S.serrata.

In the present study, it was recognized that protein was found to be abundant. Hence TLC was used for the separation of protein compounds from the samples. So it will be suggested that the study has to be extended for the characterization of protein. In the present study, the antibacterial activities of the crab extracts were recorded against different bacterial strains including E.coli, P.aeruginosa, E.aerogenes, K. Pneumoniae and S.aureus. The extracts of $S$. serrata showed uneven activities indicated different zones of inhibition [Table 1, pictures 4-7]. In the current study, the ethanol extract of crab sample I has shown high zone of inhibition in P.aeruginosa. The sample I proved moderate zone of inhibition in K.pneumoniae. The sample II showed the minimum zone of inhibition in P.aeruginosa. In the Aloe vera extracts focused high zone of inhibition in E.coli and moderate zone for S.aureus and minimum zone for K.pneumoniae. These authors concluded that the leaf extracts of Aloe vera can effectively act as an antimicrobial agent which had ability to replace most of medium medicines of this era [27]. The ethanol extract clarified that the medicinal plants which showed highest activity against strains of E.coli and minimum activity against the strains of S.aureus [28]. 
In the current analysis, the antimicrobial activity of the extracts and their potency was quantitatively assessed by the presence or absence of inhibition zone and zone diameter. Only ethanolic extract was found to be a better solvent for extraction of active antimicrobial substances compared to water and hexane [26]. In the present study, the crab samples showed antimicrobial activity against a range of different pathogenic strains of both grampositive and gramnegative bacterial strains including few antibiotic resistant strains. The results recommended that crab can produce antimicrobial substances instantly to combat bacterial infection. In general antibiotic resistance is defined by the bacteria which can still grow under achievable therapeutic concentrations of antibiotic substances at the site of infection. Resistance is related to the amount of an application of an antibiotic substance and is divided into primary or inherent resistance against an antibacterial substance and secondary or acquired resistance. Resistance become known in intrinsically susceptible bacteria, bacteria exhibited an enormous repertoire of different resistance mechanisms [29].

In the present study, the antibiotic amikacin was used as the positive control. When compared to the zone of inhibition with the amikacin, the extracts have also shown almost equal to the standard drug. The used antibiotic in the present study supported the strong scientific basis for the use of these crab extracts in traditional treatment of microbial diseases. Ewa Felis et al. [11] studied the antimicrobial pharmaceuticals in the aquatic environment and its environmental implications. These authors reported that many antibiotics have been widely prescribed for the treatment of infectious diseases. It was an aminoglycoside which plays an imperative role in aquatic environment. When compared with that study, the antibiotic amikacin revealed that it has been used as a standard drug in the pharmaceuticals for the treatment of microbial and infectious diseases. So the equivalency of the inhibition zone formed both by the used antibiotic and crab extracts proved there will be a promising hope of the compounds of the crab extracts. This study has revealed the importance of natural products to control antibiotic resistant bacteria, which have been a threat to human health. It indicated that the various parts of crabs would be a good source of antimicrobial agents and would replace the existing inadequate and cost effective antibiotics.

\section{References}

[1] S. R. Kumar, G. Ravichandran, S. Kalaivarathan, "Estimation of Biochemical Composition of Porpita porpita," Natl. Acad.Sci.Lett, vol. 32, pp. 123-128, 2008.

[2] D. Chakraborty, G. Mantha, and A. Kareem, "Study on the Growth of Post Larvae of Macrobrachium Rosenbergii (De Man) On A Copepod and A Cladoceran Livefood," Journal of Aquatic Biology, vol. 16, pp. 81-85, 2001.

[3] Giese, "Biochemical composition of mollusc body." J.Biol.chem, vol.63, pp. 461-465, 2009.

[4] Costa, Silvana \& Coppola, Francesca \& Pretti, Carlo \& Intorre, Luigi \& Meucci, Valentina \& Soares, Amadeu \& Solé, Montserrat \& Freitas, Rosa. "Biochemical And Physiological Responses Of Two Clam Species To Triclosan Combined With Climate Change Scenario." Science of the Total Environment, 2020 [Online]. Available: 138143. 10.1016/j.scitotenv. 2020.138143. [Accessed: Dec. 5, 2020].

[5] B. C.P, Susselan, "Biochemical Composition of the Deep-Water Crab Charybdis Smithii," Indian J.Fish, vol. 48, no. 3, pp. 333-335, 2001.

[6] R. Rosa and M. L Nunes, "Biochemical Composition of Deep-Sea Decapod Crustaceans with Two Different Benthic Life Strategies off The Portuguese South Coast," Deep-sea Research, vol.1, no. 50, pp. 119-130, 2013.

[7] A. Muthusamy, M. Punitha and L. Grace, "Phytochemical Screening of Datura Metel Linn and Its Antimicrobial Activity on Human Pathogens," Asian Journal of Pharmaceutical and clinical Research, vol.10, no. 12, pp. 384-386, 2014.

[8] S. Baklouti, A. Derbali, K. Dhieb, "Proximate Composition and Its Seasonality of the Mediterranean Green Crab Carcinus aestuarii nardo, 1847 (Brachyura, Portunidae) in Southern Tunisian Waters (Central Mediterranean)," Journal of Marine Biology, vol.16, pp. 36-38, 2016.

[9] B. Mia, B. Islam, M. Sarker, "Morphology and Biochemical Composition of Crab Paratelphusa lamellifrons in Bangladesh," Acad.Res.J.Bio.Sci.Med.plants, vol. 1, pp. 1-13, 2016.

[10] J. V. Keerthika, "Biochemical Composition Of Marine Crab Ocypode Brevicornis And Estuarine Crab Scylla Serrate," International Journal of Novel Trends in Pharmaceutical Sciences, vol.7, no.1, pp. 27-30, 2017. 
[11] E. Felis, J. Kalka, and A. Sochacki, "Antimicrobial Pharmaceuticals in the Aquatic Environment-Occurrence and Environmental Implications," European Journal of Pharmacology, vol. 1, no.13, pp. 866-878, 2019.

[12] A.Veeruraj, S. Ravichandran and R. Kumar, "Antibacterial Activity of Crab Haemolymph on Clinical Pathogens," Trends in Applied Sciences Research, vol. 3, no.2, pp. 174-181, 2008.

[13] D. Varadharajan and P. Soundarapandian, "Antibacterial Activity of Crab Shell Extracts against Human Pathogenic Bacteria Bacteria and Usage of New Drugs," Journal of Developing Drugs, vol.2, no.2, pp. 1000-1011, 2013.

[14] P. Du-Tie, G. Brotzu. And A. Schatz, "Antibacterial Activity of Extracts from Ink Sacs of Cuttle Fish,” J.Gen.Microbiol, vol.16, pp. 604-613, 2005.

[15] M. D. Anno, D. Choi, S. Shin, "In Vitro Evaluation of Antimicrobial and Antioxidant Activities of Algal Extracts," Int. J. Antimicrob Agents, vol.11, pp. 65-68, 2019.

[16] A. Silvana, T. Berner, and R. Johannes, "Biochemical Composition and Physiological Responses of Two Clam Species," Pacific Science, vol. 48, no. 3, pp. 224-233, 2020.

[17] O. H Lowry, N. J. Rosebrough, A.L Farr and R. J Randle, "Protein Measurement with the Folin Phenol Reagent,"Journal of Biological Chemistry, vol.193, no.1, pp. 265-275, 1951.

[18] M. Dubois, K. A Gilles, J. K Hamilton, P. A Rebers and F. Smith, "Phenol-Sulphuric Acid Method for Total Carbohydrate," Analytical Chemistry, vol. 25, pp. 350, 1956.

[19] J. Folch, M. Lees, G. H Stanley, "A simple Method for the Isolation and Purification of Total Lipids from Animal Tissues," The Journal of Biological Chemistry, vol 226, no.1, pp. 497-509, 1959.

[20] K. Fadjar, R. I Aminov and G. J Martin, "Antibacterial Activity of the Raw Ink Extracts of Cephalopods," Front Microbiol, vol.1, pp. 1-7, 2016.

[21] J. Tidwell, M. Sudhaka and K. Manivannan, "Growth, Survival and Biochemical Composition of Freshwater Prawn Macrobrachium rosenbergii," Int.J.Anim.Vet.Adv, vol.1, no. 2, pp. 44-48, 2007.

[22] K. Khawaja, "Biochemical Composition of the Muscle of Some Freshwater Fishes During the Pre-Maturity Phase," Fresh W. Biol, vol. 23, no. 3, pp. 491-503, 2010.

[23] M. Gopi, S. Kumaran et al, "Antibacterial Potential of Sponge Endosymbiont Marine Enterobacter sp. at Kavaratti Island, Lakshadweep archipelago," Asian Pacific Journal of Tropical Medicine, vol. 5, no. 2, pp.142-146, 2012.

[24] Rios, R. F. Thomas and M. Rinaudo, "Screening Methods for Natural Products with Antimicrobial Activity," J.Appl.Biol.Chem, vol. 52, pp. 84-87, 2000.

[25] D. U. Kumar, V. Christopher et al, "A Study on Distribution of Protein, Lipids and Carbohydrates in Muscle and Liver of Marine Associated Upeneus vittatus," International Journal of Pharmaceutical sciences and Research, vol. 6, no. 2, pp. 1294-1301, 2015.

[26] X. Xu, B. Yan, J. Xu and G. Xu, "Biochemical Composition Dynamics of The Ovaries and Hepatopancreas at Different Physiological Stages of The Female Marine Crab, Charybdis japonica," Journal of crustacean Biology, vol. 34, no. 1, pp. 61-69, 2014.

[27] M. K. Kaveri, Kedarnath, B. Vishwanath and C. S Pati, "Antimicrobial Activity of Aloe Vera Extract," International Journal of Applied Biology and Pharmaceutical Technology, vol. 4, no. 4, 2013.

[28] Javid, M. Adnan, A. Tariq, "Antimicrobial Activity of Three Medicinal Plants (Artesemia indica, Medicago falcata, Tecoma Stan)," Afr.J.Tradit Complement Altern Med, vol. 12, no. 3, pp. 91-96, 2015.

[29] D. Nigussie, G. Davey, B. A. Legesse, et al. "Antibacterial Activity of Methanol Extracts of the Leaves of Three Medicinal Plants Against Selected Bacteria Isolated From Wounds of Lymphoedema Patients," BMC Complement Med Ther. vol. 21, no. 2, 2021. 